\title{
Street Theatre in a State of Exception: Performing in Public after Bataclan
}

DOI:

10.1080/10486801.2020.1762584

\section{Document Version}

Accepted author manuscript

Link to publication record in Manchester Research Explorer

\section{Citation for published version (APA):}

Calder, D. (2020). Street Theatre in a State of Exception: Performing in Public after Bataclan. Contemporary Theatre Review, 30(3), 308-325. https://doi.org/10.1080/10486801.2020.1762584

\section{Published in:}

Contemporary Theatre Review

\section{Citing this paper}

Please note that where the full-text provided on Manchester Research Explorer is the Author Accepted Manuscript or Proof version this may differ from the final Published version. If citing, it is advised that you check and use the publisher's definitive version.

\section{General rights}

Copyright and moral rights for the publications made accessible in the Research Explorer are retained by the authors and/or other copyright owners and it is a condition of accessing publications that users recognise and abide by the legal requirements associated with these rights.

\section{Takedown policy}

If you believe that this document breaches copyright please refer to the University of Manchester's Takedown Procedures [http://man.ac.uk/04Y6Bo] or contact uml.scholarlycommunications@manchester.ac.uk providing relevant details, so we can investigate your claim.

\section{OPEN ACCESS}


Street Theatre in a State of Exception: Performing in Public after Bataclan

\author{
Dr David Calder \\ University of Manchester \\ david.calder@manchester.ac.uk
}

OrcID: https://orcid.org/0000-0002-3367-9238 


\title{
Street Theatre in a State of Exception: Performing in Public after Bataclan
}

\begin{abstract}
This paper analyses the response of French street theatre to France's state of emergency (2015-2017). It analyses the emergency (and the broader state of exception) as a reconfiguration of space and time that has altered the conditions from which street theatre might claim space as public. Since the 2015 Paris terror attacks and the ensuing declaration of emergency, how has street theatre attempted to create spaces of possibility and imagine alternative futures in a restricted public sphere? I examine how the state of emergency affected the Aurillac Festival, France's largest annual street theatre festival, in 2016 and 2017. The response of street theatre practitioners and festivalgoers to heightened security measures in 2016 reveals a tension between order and disorder and a potentially inescapable bind: street theatre's advocates appeal to a rule of law that has already been suspended and to a liberal, universalist conception of public space that, in France at least, has always been structured by the logic of the exception. But analysis of Aurillac 2017 shows how, in performance, street theatre might re-form the precarity of bodies in a state of exception and model the formation of an interdependent public.
\end{abstract}

Keywords: street theatre, public space, state of exception, precarity

At five minutes to midnight, on Friday, 13 November 2015, France's thenPresident François Hollande declared a national state of emergency. The announcement followed a series of terrorist attacks at the Stade de France, several cafe terraces in the tenth and eleventh arrondissements of Paris, and the Bataclan 
nightclub, which together left 130 people dead. In accordance with law no. 55-385 of 3 April 1955 (known simply as 'the 1955 law'), Hollande was able to unilaterally declare a state of emergency (état d'urgence) provided he seek parliamentary authorisation within twelve days. Just six days after Hollande's declaration, the Senate granted its nearly unanimous approval. ${ }^{1}$ Although the initial period of the state of emergency was set at three months, parliamentary support remained strong through six extensions. On 14 July 2016, Hollande announced that he would end the state of emergency on 26 July 2016. But a mere few hours later, another terrorist attack killed 86 people at Bastille Day celebrations in Nice. The state of emergency remained in effect. In total it would last nearly two years (719 days), ending at midnight on 1 November 2017.

In what follows I analyse France's 2015-2017 state of emergency, and its mutation into a generalised state of exception, as reconfigurations of space and time that pose a challenge to the other reconfigurations of space and time characteristic of contemporary French street theatre. The connection is an important one, firstly, because street theatre takes as both its site and its form the contested contours of public space. The terms of that contest--the physical spaces in which street theatre might take place and the repertoire of behaviours available within those spaces--have been radically altered by the technologies and discourses of the so-called War on Terror and the contemporary security state. Agents of the security state have contributed to the restricting and restructuring of public spaces and the prising open of private ones. The securitisation of public space has occurred alongside its ongoing privatisation and marketization: video surveillance and security personnel, for instance, are not tools unique to the State; private companies deploy them to monitor

\footnotetext{
${ }^{1}$ Six of 348 Senators voted against implementing the state of emergency.
} 
behaviour, discourage loitering, and enforce consumption in the pseudo-public spaces of the contemporary city. ${ }^{2}$ This is the shifting terrain in and on which street theatre works. Public space has never been a given, and, in France, street theatre has historically played a role in claiming space as public. But the state of emergency radically altered the conditions from which street theatre practitioners might make such claims.

The connection between France's state of emergency and its street theatre is also important because of how the logic of the exception has structured street theatre's claims to political efficacy. I take as axiomatic the link, traced by Jenny Hughes, between exception and performance:

[A] state of exception is produced by means of a performance--a declaration-of power that may or may not be written in law, and this power is both made and contested in an embodied and performative zone that is not securely definable or fixable. Performance, in its play of guises, appearances and disappearances, performative enunciations, shifting empirical and imagined realities, tangible materiality and fantastic pretence, is perfectly suited to act as a key agent in this terrain. ${ }^{3}$

The link is stronger still in the case of contemporary French street theatre, which claims to suspend the rules of the everyday and grounds those claims in the historical antecedents of charivari and carnival. ${ }^{4}$ Giorgio Agamben cites those historical

\footnotetext{
${ }^{2}$ On the increasing privatisation of public space, see David Harvey, Rebel Cities: From the Right to the City to the Urban Revolution (London: Verso, 2012), in particular Chapter 1, 'The Right to the City.' See also Thomas Moreau, 'Reprendre l'espace public,' Ballast 20 June 2017 (https://www.revue-ballast.fr/reprendre-lespacepublic/).

${ }^{3}$ Jenny Hughes, Performance in a time of terror: Critical mimesis and the age of uncertainty (Manchester: Manchester University Press, 2011), 4-5.

${ }^{4}$ Charivari was a festive shaming practice common in the late medieval and early modern periods. Masked young people would gather beneath the window of a
} 
phenomena, which he calls examples of 'anomic feasts,' as 'inverse figure[s]' of the state of exception. ${ }^{5}$ For Agamben, this 'legal anarchy' parodies the anomie contained within the law; charivari and carnival are modelled on the state of exception insofar as the state of exception is the suspension of the law at the heart of law itself.

What does this mean for contemporary street theatre? Street theatre's political efficacy is supposed to derive from its transgression of boundaries, its overturning or levelling of hierarchies, and its suspension (however fleeting) of prevailing rules. But that work becomes more complicated when, as Agamben argues, the suspension of law has shifted from a temporary response to delimited crisis (what I call a state of emergency) to the prevailing and enduring operational mode of supposedly democratic states (what Agamben calls the state of exception). ${ }^{6}$ If street theatre practitioners and scholars are to make claims for the form's political efficacy, they must ground those claims in rigorous understanding of the conditions in and on which street theatre attempts to operate. I contend that it is insufficient to celebrate street theatre as an overturning or suspension of rules when the suspension of rule has become the rule.

Here I examine how the state of emergency affected the Aurillac Festival, France's largest annual street theatre festival, in 2016 and 2017. In the first section, I

perceived moral wrongdoer, bang pots and pans, and sing humiliating songs. See Charles Tilley, 'Charivaris, repertoires, and urban politics,' in French Cities in the Nineteenth Century, ed. John Merriman (London: Hutchinson \& Co., 1982), 73-91; and Natalie Zemon Davis, 'The Reasons of Misrule: Youth Groups and Charivaris in Sixteenth-Century France,' Past \& Present 50 (1971): 41-75.

${ }^{5}$ Giorgio Agamben, State of Exception, trans. Kevin Attell (Chicago: University of Chicago Press, 2005), 71.

${ }^{6}$ Ibid. 2-3. The distinction between 'state of emergency' and 'state of exception' varies by author and is complicated by issues of translation. I refer to the delimited period from 2015-2017 in France as a 'state of emergency,' the most direct translation for the French état d'urgence. I follow Attell's translation of Agamben and use 'state of exception' to refer to the suspension of the juridical order that has become (in Agamben's view) a permanent state. 
argue that the response of street theatre practitioners and festivalgoers to heightened security measures in 2016 reveals a tension between order and disorder in the defence of public space. This leads street theatre into a potentially inescapable bind: street theatre's advocates appeal to a rule of law that has already been suspended and to a liberal, universalist conception of public space that, in France at least, has always been structured by the logic of the exception. But in the second section I demonstrate that, if the states of emergency and exception pose a challenge to street theatre by reconfiguring space and time, then street theatre's spatiotemporal play makes it ideally suited to respond with a challenge of its own. Analysis of the Aurillac festival's nonlinear temporality and its 2017 inaugural event shows how street theatre can render the exception differently intelligible and navigable, re-form the precarity of bodies, and model the formation of an interdependent public. Ultimately, this study asks how street theatre might take exception to an exception become the rule. In other words, how is street theatre to be political in exceptional times?

\section{Private Citizens, Public Spaces: Aurillac 2016 and its Aftermath}

Restrictions on street theatre festivals during France's state of emergency were part of a broader shift in the spatial and temporal dynamics between public and private. The 1955 law authorised 'administrative searches' (perquisitions administratives), a euphemism for police raids requiring no judicial approval or oversight. More than 4,600 were carried out during the state of emergency, some of which resulted in bodily injury and property damage. ${ }^{7}$ As a suspension of the rule of

\footnotetext{
${ }^{7}$ For statistics on administrative searches, see Soren Seelow, 'Une efficacité difficile à mesurer,' Le Monde, 2 November 2017: SPA4. For reports on injury and property damage, see Jean-Baptiste Jacquin and Julia Pascual, 'Un an, 11 mois et 18 jours d'urgence,' Le Monde, 2 November 2017: SPA2.
} 
law, the state of emergency transferred from the judiciary to the police the authority to open private spaces (anywhere except lawyers' offices) to the violent scrutiny of the forces of public order. It also enabled those forces to infringe upon private time. The Constitution typically maintains the 'inviolability of the domicile': judges may authorise the searching of private residences, but except in extraordinary circumstances they confine those searches to the 'judicial hours' between six o'clock in the morning and nine o'clock at night. By contrast, in the first week following the November terror attacks $68 \%$ of raids were carried out at night. ${ }^{8}$ The state of emergency generalized the law's 'extraordinary circumstances.'

The 1955 law also authorised police to place persons, including minors, under house arrest without judicial involvement. Burden of proof was transferred to the accused, even if the accused was not actually accused of anything. The person placed under house arrest had 'to demonstrate that he $[$ sic $]$ does not represent a threat.' ${ }^{19}$ Because it is impossible to prove a negative, no appeals against house arrest were successful. The mother of one minor placed under house arrest for over a year described her home as a 'house become a prison. ${ }^{10}$ For those targeted by administrative searches, the boundaries separating private space and time from public were forcibly prised open; for others, private space and time became forced enclosures.

The reconfiguration of public and private spaces and times did not apply just to 'suspect' individuals and their families. The 1955 law permitted the Interior

\footnotetext{
${ }^{8}$ Nicolas Raffin, 'Un an après, le bilan mitigé de l'état d'urgence,' La Tribune, 15 December 2016: 27. All translations from French are my own unless otherwise specified.

${ }^{9}$ Jacquin and Pascual, 'Un an,' SPA2.

${ }^{10}$ Quoted in Jean-Baptiste Jacquin and Julia Pascual, 'Je serais terroriste parce que musulman,' Le Monde, 2 November 2017: SPA4.
} 
Minister and departmental authorities to temporarily close 'auditoria, public houses and meeting places of any kind.' An amendment to Article 8 of the 1955 law, which took effect during the state of emergency in July 2016, specified places of worship as examples of those meeting places and granted authorities heightened powers to restrict movement in public space: 'Processions, marches and gatherings of persons on a public thoroughfare [sur la voie publique] may be prohibited from the moment the administrative authority judges that it is not in a position to insure safety given the means at its disposal. ${ }^{\prime 11}$ During the state of emergency police closed more than two dozen mosques and placed numerous restrictions on public gatherings. The state of emergency proved a useful framework for prohibiting or limiting participation in protests unrelated to terrorism under the guise of concern for public safety; hundreds of anti-fascist protestors were arrested so they could not participate in planned demonstrations against changes to labour law. ${ }^{12}$

The State did not directly intervene in festivals and other cultural appropriations of public space, but during the state of emergency the imperative to provide for public security--and the costs and logistics of doing so--wreaked havoc on even the best-known events. Municipal governments cancelled or restricted numerous public markets and festivals, citing security concerns. In 2016, Lille mayor Martine Aubry cancelled the city's street market, the largest in Europe, expected to draw two million visitors; it was the first cancellation of the annual event since the Second World War. ${ }^{13}$ Aubry herself lamented the move but explained she was unable to guarantee the security of so many visitors at an event that would occupy much of the

\footnotetext{
${ }^{11}$ Loi n ${ }^{\circ}$ 55-385 du 3 avril 1955 relative à l'état d'urgence. Available at: https://www.legifrance.gouv.fr/affichTexte.do?cidTexte=JORFTEXT000000695350

12 Jacquin and Pascual, 'Un an,' SPA2

${ }^{13}$ Le Monde with Agence France-Presse, 'La braderie de Lille annulée pour raison de sécurité,' Le Monde, 5 August 2016
} 
city centre. The more diffuse an event, the more difficult to establish a secure perimeter. Annual festivals in Dax and Lorient were able to proceed, but only by strictly controlling access to the respective town centres with barriers, checkpoints, and hundreds of private security guards. ${ }^{14}$ A 2017 guide for cultural event organisers prepared jointly by the Ministries of the Interior and Culture and Communication placed the onus for public safety and security firmly on the shoulders of event organisers and municipalities. Event organisers had previously been expected to provide for public safety--the minimization of risk of accidents and preparation for possible unintended medical emergencies, for instance--but the guarantee of public security--protection against intentional threats such as terrorism--had previously been the sole responsibility of the State. Although the State might provide limited support in the form of a company of riot police, municipalities and festival organisers now found themselves relying primarily on private security firms. The money for such contracts came not from defence or police budgets but from public culture spending.

Heightened security measures dominated news coverage of the 2016 Aurillac street theatre festival (17-20 August) and the space of Aurillac itself. ${ }^{15}$ Police and private security forces tightly controlled access to the town centre. Because of the nature of the Nice attack just over a month before, town council and festival organisers closed several major roads to non-pedestrian traffic. Concrete bollards,

\footnotetext{
${ }^{14}$ Sarah Belouezzane and Olivier Faye, 'Conscients du danger terroriste, des maires renforcent la sécurité des festivals,' Le Monde, 5 August 2016

${ }^{15}$ Sarah Belouezzane and Olivier Faye, 'Conscients du danger terroriste'; Culturebox with Agence France-Presse, 'Festival de théâtre de rue d'Aurillac: une "30e edition bis" sous haute surveillance,' Culturebox, 15 August 2016 (https://culturebox.francetvinfo.fr/culture/la-france-des-festivals/festival-de-theatrede-rue-d-aurillac-une-30e-edition-bis-sous-haute-securite-244569); Lefigaro.fr with Agence France-Presse, 'Aurillac: le festival de théâtre sous surveillance,' Lefigaro.fr, 15 August 2016 (http://www.lefigaro.fr/flash-actu/2016/08/15/9700120160815FILWWW00032-aurillac-le-festival-de-theatre-sous-surveillance.php)
} 
steel barriers and chains were installed to block vehicles and ensure that pedestrians entered the town centre through one of nine designated checkpoints. There, security forces searched every bag at a festival where attendance was estimated at over 100,000 people. Glass bottles, alcohol, luggage, and large bags were prohibited within the secured area. Organisers provided a free left-luggage office but urged festivalgoers to leave banned items at their hotels or campsites in order to save time. Though most of the festival's 'Off' (fringe) performers set up inside the town centre to attract casual passers-by, several of the 'In' (programmed) companies each year perform elsewhere in and around Aurillac in an effort to better integrate the festival with the local surroundings; in 2016, these shows required their own, separate security checks. Place des Anges, an aerial spectacle that closed the festival on Saturday, 20 August, did take place in (and above) the central secured area but was still subject to an additional layer of security: checkpoint staff conducted pat-downs of the 5,000 people in attendance. In all, heightened security measures cost the festival 250,000 euros, with additional financial support provided by the Ministry of Culture. $^{16}$

On Friday, 19 August 2016, shortly after six in the evening, resentment of such heightened security measures and of the security state more generally became a demonstration. Protestors broke through a checkpoint into the town centre, distributing tracts denouncing 'private, military, and police deployment' likened to being 'put in a cage. ${ }^{17}$ Some demonstrators tore down the stainless steel fencing that formed part of the security perimeter and tossed it into a pile in the Place des Carmes.

\footnotetext{
${ }^{16}$ Michel Guerrin, 'Les arts de la rue face au défi sécuritaire,' Le Monde, 14 October 2016

${ }^{17}$ Quoted in 'Etat d'urgence: violente manifestation contre les fouilles au Festival d'Aurillac,' Le Monde, 20 August 2016
} 
Some added rubbish bins to the heap and set them alight. Others threw stones at windows. The square soon became the site of a clash between an estimated three hundred demonstrators and fifty mobile gendarmes, who fired tear gas into the crowd. The skirmish lasted for nearly two hours, but by 8:30 PM festivalgoers were assisting with the clean-up.

Varying reports assigned festivalgoers to different sides of the conflict. JeanFrançois Bauvois, director of the cabinet for the Cantal prefecture, placed attendees opposite the apparent instigators: 'There were sharp exchanges between hooligans [casseurs] and festivalgoers, the latter not understanding their motivations for putting the security presence in peril. ${ }^{18}$ Aurillac Mayor Pierre Mathonier explained, 'Between 20 and 30 agitators wanted to force their way through a security queue, sweeping along [entraînant] festivalgoers, [who were] discontented by the security presence that was slowing them down. ${ }^{19}$ Le Monde described the crowd as '300 festivalgoers, infiltrated by a hundred hooligans [casseurs], some in balaclavas. ${ }^{20}$ La Montagne writer Gilles Lalloz reports that a group 'had come to confront' security forces, but he describes that group as 'festivalgoers' (festivaliers). ${ }^{21}$ Did festivalgoers confront hooligans, or were they infiltrated by them? Were they swept up by agitators, or were they the agitators? The answer is likely 'yes': these options are not mutually exclusive, because the unwieldy term 'festivalgoers' does not name a monolith. But the uncertainty, and the eagerness of festival organisers to distinguish between

\footnotetext{
${ }^{18}$ Ibid.

${ }^{19}$ Ibid.

20 'Etat d'urgence: violente manifestation contre les fouilles au Festival d'Aurillac,' Le Monde, 20 August 2016.

${ }^{21}$ Gilles Lalloz, 'Affrontements à Aurillac: le festival de théâtre de rue entaché,' La Montagne, 20 August 2016.
} 
demonstrators and festival attendees, raises questions about the role of street theatre in public space and its relationship to public order.

The tracts distributed by demonstrators argued that 'the tension generated by the police presence and by the security guards' bag searches [was] changing the tone of the festival. ${ }^{12}$ Philippe Meyer, president of the Association Éclat that organises the festival, responded:

Those who claimed that the measures to protect the population "have generated a tension (that) has changed the tone of the festival" are not only out-and-out liars. They are the ones responsible for the only moments of discord and violence of the festival, and [their claims] are refuted by the calm of the artists and of the population. ${ }^{23}$

Meyer, however, misidentifies one of the demonstrators' key complaints. The tract does not criticise the security presence as a disruption to a festival that would otherwise have proceeded calmly; on the contrary, it laments the heightened security as a disruption to the disruption that, in the demonstrators' view, street theatre should be. The 'calm' noted by Meyer so favourably was, for the anonymous authors of the tract, precisely the problem, evidence of order imposed on disorder. My point here is not to dismiss the concerns of festival organisers as somehow anti-radical; it is indeed difficult to perform in a street that has been ripped up and set on fire. My point, rather, is that the debate over the 'tone' of the festival--the questions surrounding who or what was disrupting whom or what--indicates a broader debate about the

\footnotetext{
${ }^{22}$ Quoted in 'Video: Affrontements entre forces de l'ordre et festivaliers à Aurillac,' La Montagne, 19 August 2016 (https://www.lamontagne.fr/auvergne/actualite/2016/08/19/video-affrontementsentre-forces-de-l-ordre-et-festivaliers-a-aurillac 12040096.html\#refresh). Unsurprisingly, the conflict continued in the comments section. No good has ever come of reading the comments, so I will not quote them here.

${ }^{23}$ Lalloz, 'Affrontements'
} 
reconfiguration and reconceptualization of street theatre's politics in a state of exception.

Central to that debate, and to understanding the state of exception more generally, is the concept of order. Carl Schmitt explains that, in the suspension of the existing order that constitutes the state of exception, 'the state remains, whereas law recedes. Because the exception is different from anarchy and chaos, order in the juristic sense still prevails even if it is not of the ordinary kind. ${ }^{24}$ In other words, the state of exception reveals the 'conceptual independence' of law and order: the law recedes, while order remains..$^{25}$ Or, as Agamben argues, the state of exception is an 'emptiness of law,' a 'space devoid of law,' that makes possible a 'force of law without law. ${ }^{26}$ As the earlier examples of administrative searches and house arrests illustrate, judicial powers transfer to the police, who claim to uphold and enforce a law the application of which has been suspended; what they maintain is not in fact law, but order. After the 2016 Aurillac protest, French reports referred to the mobile gendarmes as 'les forces de l'ordre,' the standard umbrella term for any State police (or, in the case of the mobile gendarmes, military) tasked with crowd control, riot dispersal, and the maintenance of public order. ${ }^{27}$ Though typically rendered in English as 'law enforcement officers,' the term literally translates to 'forces of order,' and, in the state of exception, this more direct translation is also the more accurate. Festival demonstrators were protesting, not disorder, but the enforced ordering of disorder. If

\footnotetext{
${ }^{24}$ Carl Schmitt, Political Theology, trans. George Schwab (Chicago: University of Chicago Press, 2005 [1922]), 12.

${ }^{25}$ Ibid.

${ }^{26}$ Agamben, State of Exception, 6, 50, 39.

${ }^{27}$ Unlike CRS officers, who are civilian police, the mobile gendarmerie is a branch of the French military.
} 
anything they were upholding festival director Jean-Marie Songy's claim that '[w]e [street performers] are the professionals of urban disorder. ${ }^{128}$

Against the forces of order, street theatre practitioners invoked the law: a potentially futile gesture, given that the state of exception is a suspension of the rule of law, and that such a suspension lies at the heart of law itself. In the months following the 2016 Aurillac festival, amidst the ongoing state of emergency, organisers, artists, and allies advocated for street theatre using a rights discourse grounded in French and international law. A manifesto prepared in the run-up to the 2017 legislative elections argued that artists 'are also quite simply citizens' and sought 'to affirm the values that are at the heart of [their] practices and at the heart of the republican pact. ${ }^{29}$ The manifesto explicitly linked street theatre, as a form of expression in the public sphere, to the freedoms and values enshrined in the French Constitution and in the Universal Declaration of Human Rights. President of the National Federation for Street Arts Lucile Rimbert echoed the rights discourse of the manifesto in her criticism of proposed security measures for the 2017 Aurillac festival. In an open letter, Rimbert argued that '[t]o enclose the festival of Aurillac $[\ldots]$ is also to reduce the rights of citizens, to prevent the meetings of all the children of the Republic':

We are citizens, faced with a historic turning point. Will we allow ourselves to reduce our common goods to a single use and lastingly hinder our freedom of expression and of circulation to live in cities [that have] become private? We

\footnotetext{
${ }^{28}$ Clarisse Fabre, 'A Aurillac, le théâtre de rue sous contrôle,' Le Monde 18 August 2017 (https://www.lemonde.fr/scenes/article/2017/08/18/a-aurillac-le-theatre-de-ruesous-controle_5173902_1654999.html).

${ }^{29}$ Fédération nationale $\overline{d e s}$ arts de la rue, 'Manifeste pour la création artistique dans l'espace public,' January 2017, 4, 5. See also 'La France en état d'urgence culturelle,' Libération 19 June 2017 (https://www.liberation.fr/debats/2017/06/19/la-france-enetat-d-urgence-culturelle_1577861).
} 
cannot negotiate with the rights of Man, founders of our Republic. [...] We cannot accept the privatisation and standardisation of public spaces and spaces of circulation. We will not capitulate, and will continue to defend the totality of our liberties, will continue to create, to dream, to gather, for our humanity. ${ }^{30}$ Manifesto and open letter take public space as the necessary precondition for the exercise of freedom of expression. They build on that premise to suggest that to enclose public space is to limit that freedom of expression; in other words, to restrict the circulation of bodies in public space is to restrict the circulation of ideas in the public sphere. Disorderly street theatre fights the forces of order with recourse to the rule--not force--of law. Without that rule of law, street theatre appears ontologically insecure.

Though recourse to rights discourse positions street theatre on the side of law, it is a risky rhetorical move. For one, French law treats both liberty and security as fundamental rights. When activists claim their right to liberties (e.g. the freedom of expression), the State may simply counter that it must ensure the protection of all rights by attempting to strike the right balance between liberty and security. (The language of balance permeates media coverage of and official statements on the state of emergency, disguising radical transfers of power as somehow moderate.) By basing their claims in the French Republic's foundational documents, street theatre advocates also risk inheriting the problems of the Enlightenment liberalism in which those documents are steeped and that they helped to codify. Documents like the manifesto and the open letter critique the privatisation of public space whilst implicitly espousing an individualist view of life and liberty as private possessions to be

\footnotetext{
${ }^{30}$ Lucile Rimbert, 'Lettre ouverte de la Fédération nationale des arts de la rue: Quel monde voulons?' L'Humanité 30 July 2017 (https://www.humanite.fr/lettre-ouvertede-la-federation-nationale-des-arts-de-la-rue-quel-monde-voulons-639524).
} 
protected from external interference. Enlightenment liberalism eschews interdependency and assumes a bounded, autonomous human subject. Liberal defences of street theatre also repeat rights discourse's conflation of human and citizen. As Wendy Brown argues, rights create subjects, and so contribute to restrictive understandings of the human. ${ }^{31}$ According to the logic of France's founding documents, French citizens are human--and therefore possessed of human rights--only insofar as they are citizens. Particularly at a historical moment when governments threaten to strip suspect persons of their citizenship (thereby rendering them inhuman in the eyes of the law), should street theatre's advocates move beyond statements of their rights as citizens in their defence of public space?

My purpose here is not to suggest that all rights discourse must be abandoned but to point to its limitations in this means of defence. Street theatre advocates claim public space as the necessary precondition for the freedom of expression. But, remarkably, the concept of public space entered French law only in 2010, in the form of the controversial 'burqa ban.' The 11 October 2010 law banned 'the dissimulation of the face in public space. ${ }^{32}$ Thus, in juridical terms, public space is defined negatively, as a site where freedom of expression may be restricted in the interest of public order. ${ }^{33}$ Although the ban's supporters framed it as a feminist triumph that

\footnotetext{
${ }^{31}$ Wendy Brown, 'Suffering Rights as Paradoxes,' Constellations 7.2 (2000): 230-41. ${ }^{32}$ Loi $\mathrm{n}^{\circ}$ 2010-1192 du 11 octobre 2010 interdisant la dissimulation du visage dans l'espace public. Available at: https://www.legifrance.gouv.fr/affichTexte.do?cidTexte=JORFTEXT000022911670 $\&$ categorieLien $=$ cid. Although earlier laws had referred to the public thoroughfare or the public way (la voie publique), the 2010 ban established the legal existence of public space (l'espace public), which included thoroughfares and parks but also extended into indoor spaces such as schools and government buildings. See Cécile Chambraud, 'L'espace public doit-il être neutre?' Le Monde 17 February 2016; and Laure Ortiz, 'L'espace public en état d'urgence,' Multitudes 67.2 (2017): 3-7. ${ }^{33}$ See Anne Gonon, 'Troubles à l'ordre public?' stradda no. 38/9 (2016): 53-4. Gonon and Laure Ortiz observe that the face concealment ban has as its stated goal the defense of public order and not of secularism. Similar logic underpins face
} 
guaranteed women's unfettered access to the public sphere, for Judith Butler, the arrest and deportation of veiled women in France 'clearly denies their rights to appear in public as they will. ${ }^{34}$ In Butler's words, the right to appear 'is tacitly supported by regulatory schemes that qualify only certain subjects as eligible to exercise that right. Thus, no matter how "universal" the right to appear claims to be, its universalism is undercut by differential forms of power that qualify who can and cannot appear,' and in what guise. ${ }^{35}$ The French law on which street theatre advocates build their claims presupposes a universalism that is proved fraudulent by the subsequent legal framing of public space. To have the right to access public space, one must adhere to secular (implicitly Christian) norms, in a performance of 'proper' Frenchness. Public space becomes the reserve of a universalized 'us,' defined against an excluded--and yet, internal--'them.'

Thus, in France, public space as a juridical concept is built upon the policing of an internal Other: the very distinction between friend and (domestic) enemy that undergirds the exception and is illustrated by the history of France's state of emergency. ${ }^{36}$ The 1955 law was created in the midst of the Algerian War of Independence. It is crucial to our understanding of the state of emergency that, for the French government, this conflict was a civil war: the threat was internal, within the

concealment bans in Austria, Belgium, Denmark, Germany, Italy, Latvia, the Netherlands, and Sweden.

${ }^{34}$ Judith Butler, Notes toward a performative theory of assembly (Cambridge, MA: Harvard University Press, 2015), 49. My emphasis.

${ }^{35}$ Ibid. 50.

${ }^{36}$ Carl Schmitt observes in The Concept of the Political that 'a state's requirement for internal peace compels it in critical situations to decide also upon the domestic enemy.' Carl Schmitt, The Concept of the Political, trans. George Schwab (Chicago: University of Chicago Press, 2007 [1932]), 46. More recently, Agamben has argued that de-politicized citizens are mobilized through 'fear of a foreign enemy who is not solely external to them.' Giorgio Agamben, 'De l'Etat de droit à l'Etat de sécurité,' Le Monde 24 December 2015: 16. 
nation's borders, and indeed at the heart of Frenchness itself. In 1955, Algerians were French insofar as Algeria was, at the time, an overseas department rather than a colony or territory. But they were also not French: French colonialism, cultural imperialism, and departmental administration assumed whiteness and Catholicism as default markers of Frenchness; thus, the mere existence of Muslim people of colour became a failure to assimilate, an obstinate refusal to perform Frenchness properly. This logic persisted through the two subsequent invocations of the 1955 law: in 1984 in New Caledonia (another overseas department) and in 2005 during the riots in France's banlieues. As Khaled Beydoun observes, those riots marked a transition in the French state's approach to terrorism, 'supplant[ing] fears of the terrorist outsider with the homegrown radical. ${ }^{137}$ But instead of tackling discriminatory policing, poverty, and high unemployment, the French state and its police doubled down on assimilationist policies. The internal threat had relocated from overseas departments to the metropolitan suburbs.

In 2015, as in 1955 and 2005, France waged a war against the Other within. Though the state of emergency covered the entirety of the French territory, it was differentially applied and experienced. Administrative searches and house arrests were overwhelmingly concentrated in the already precarious banlieues. ${ }^{38}$ Reflecting on the state of emergency after its official end in 2017, Patrice Spinosi writes,

Certainly, when one is well situated, in the city or in the country and integrated, the state of emergency does not seem to have taken hold of the

\footnotetext{
${ }^{37}$ Khaled A. Beydoun, 'Beyond the Paris Attacks: Unveiling the War Within French Counterterror Policy,' American University Law Review 65 (2016): 1273-334 (12878).

${ }^{38}$ Dominique Raimbourg and Jean-Frédéric Poisson, 'Rapport d'information sur le contrôle parlementaire de l'état d'urgence,' report presented to the National Assembly, 6 December 2016, 33-9. See also Beydoun, 'Beyond the Paris Attacks,' 1317.
} 
everyday. But go talk to people in difficult quarters, the banlieues, the places of that other France, that which it is so easy to stigmatise and that fights to survive. You will see that the experience is not the same. ${ }^{39}$

The state of emergency granted police expanded powers to wage war against 'that other France,' a domestic enemy, internal to France but against which the nation might define and secure itself.

A defence of street theatre grounded in recourse to law and the rights of citizens ignores, first, law's subordination to order in the state of exception, and second, the shared logics of the exception and liberal polity. As demonstrated above, the state of exception and the juridical concept of public space are both founded upon a distinction between 'us' and 'them' that treats French Muslims as threats to public order. Street theatre's advocates cannot accept at face value the liberal-universalist conception of public space, as public space only legally exists as a site where public order is maintained. When street theatre attempts to lay claim to a liberal-universalist public space, it runs into the problem of who counts as part of that public. In the following section I turn my attention from how street theatre advocates have attempted to claim public space to how street theatre practitioners claim a different relation to both space and time. ${ }^{40}$ At Aurillac 2017, street theatre performers staged an experiment in public formation, attempting to re-create public space rather than

\footnotetext{
${ }^{39}$ Patrice Spinosi, 'On n'arrête pas les attentats avec des lois,' Le Monde 2 November 2017: SPA7.

${ }^{40}$ In a different context, Jade Power-Sotomayor has suggested that performers and performance scholars rethink the too-often colonialist gesture of claiming space, claiming instead a different relation to space and place. Jade Power-Sotomayor, 'Corporeal Sounding: Listening to Bomba Dance, Listening to Puertoriquenxs,' American Society for Theatre Research Conference, Arlington, VA, 9 November 2019.
} 
assuming it as given. The opening ceremony of Aurillac 2017 suggests how street theatre might turn its own exceptional logic against that of the security state.

\section{Uncertain Times, Vulnerable Bodies: Aurillac 2017}

Though France's state of emergency, governed by the 1955 law, is distinct from the 'state of war' provided for in Article 36 of the French Constitution, the language of war--what Christian Lequesne calls 'warrior discourse'--has pervaded the political and legal aftermath of the November 2015 attacks. ${ }^{41}$ Declaring the state of emergency, Hollande announced, 'To all those who have seen these awful things, I want to say we are going to lead a war which will be pitiless. ${ }^{142}$ Then-Prime Minister Manuel Valls echoed Hollande's rhetoric, using the word 'war' nine times in a tenminute media appearance. ${ }^{43}$ The government's subsequent actions (including the first increase in military spending in 25 years) and their legal justification brought an end to French exceptionalism in anti-terror policy and a shift towards an American-style 'war on terror.' 44

As numerous commentators have pointed out, a war on terror is selfperpetuating and potentially endless. Hughes rightly notes, 'Wars on terror are effectively durational performances, lacking a beginning, middle and end, and characterised by temporal and spatial formlessness. ${ }^{45}$ As an abstract concept, terror is unable to surrender, and as an emotion, terror is generated or intensified by the very

\footnotetext{
${ }^{41}$ Christian Lequesne, 'French foreign and security challenges after the Paris terrorist attacks,' Contemporary Security Policy 37.2 (2016): 306-18 (308).

${ }^{42}$ Quoted in English translation in Beydoun, 'Beyond the Paris Attacks,' 1277.

${ }^{43}$ Lilian Alemagna and Laure Bretton, 'Manuel Valls: "Nous sommes en guerre,"' Libération 14 November 2015 (https:/www.liberation.fr/france/2015/11/14/manuelvalls-nous-sommes-en-guerre_1413503).

${ }^{44}$ Lequesne, 'French foreign and security challenges,' 314.

${ }^{45}$ Hughes, Performance in a time of terror, 15.
} 
war that would see its end. Thus, though the wording of the 1955 law stresses its partial and temporary nature as a response to imminent threat, the possibility of indefinite war quickly emerged as a concern following the declaration of the state of emergency. In a November 2015 interview, legal historian François Saint-Bonnet warned that during 'an exceptional period, authorities sometimes have a tendency to confuse measures for the restoration of an order that is under threat with the installation of a new order. ${ }^{46}$ The state of emergency was always implemented for a fixed amount of time (usually three months), but after repeated parliamentary extensions it assumed an indefinite character. ${ }^{47}$ The threat of terrorism was perceived as both imminent and durational.

Following the official end of the state of emergency in 2017, commentators attempted to frame it as a bounded historical event, perhaps in the hope that the emergency was indeed over, that the exception had ceded to the rule that once was. Jacquin and Pascual referred to the emergency as a 'temporal window' during which 'France had to put in parentheses the European Convention of Human Rights,' and suggested that both window and parentheses had finally closed. ${ }^{48}$ But the logic of the exception had created a political conundrum (or, for proponents of the security state, a political opportunity). Hollande could only declare the state of emergency and subsequently extend it based on an imminent threat. The state of emergency became

\footnotetext{
${ }^{46}$ François Saint-Bonnet, 'Plus la latitude du pouvoir est grande, plus les citoyens doivent être vigilants,' lemonde.fr 26 November 2015: n.p.

${ }^{47}$ See Olivier Beaud, 'Il ne faut pas constitutionnaliser l'état d'urgence.' Le Monde, 2 December 2015: 15. Just weeks into the state of emergency, Beaud warned that multiple extensions would risk transforming it into a permanent state. See also Jacquin and Pascual, 'Un an,' SPA2. Jacquin and Pascal observe that the government would pay lip service to the temporary nature of the state of emergency as a preamble to each extension.

48 Jean-Baptiste Jacquin and Julia Pascual, 'Sortir de l'état d'urgence,' Le Monde 2 November 2017: SPA1.
} 
more and more unpopular as it wore on, but the threat--something so vaguely defined as 'terror'--had not diminished. As Hollande discovered in July 2016 when he attempted to end the state of emergency just hours before the terror attack in Nice, there was considerable political risk to ending the state of emergency prior to the (impossible) elimination of all terrorism. ${ }^{49}$ Thus, 'in order to close the parentheses of the state of exception,' Hollande's successor Emmanuel Macron transposed most of the provisions of the state of emergency into common law, allowing for its permanent continuation. ${ }^{50}$ The parentheses closed, but the exception remained; at the time of writing the French continue to live under permanent and imminent threat.

During France's state of emergency, the Aurillac street theatre festival marked a time out of joint. Seasonal festivals typically keep cyclical time. Annual festivals (also) keep even, linear time, as each iteration of the event is duly counted off: the $30^{\text {th }}$ annual festival of street theatre, the $31^{\text {st }}$ annual festival, and so on. But in March 2016, Aurillac festival director Jean-Marie Songy announced that that summer's festival would not be the $31^{\text {st }}$ edition (following logically from the $30^{\text {th }}$ edition in August 2015), but the $30^{\text {th }}$ edition bis. When it follows a number, the French bis (roughly translating to 'again' or 'alternative') evokes the numbering of subdivided or newly inserted houses, an interruption to the neat progression of street addresses. It also refers to concertgoers' cries for an encore, forestalling the end of an event. None of the performances from the $30^{\text {th }}$ edition in 2015 was re-programmed for the encore in 2016, but Songy called the latter event a kind of rattrapage: a retake, a resit, a putting right. Songy remarked, 'we wanted to say that we could have fun with time,

\footnotetext{
49 The political risk of ending the state of emergency was noted by Jean-Christophe Chanut in December 2015. Jean-Christophe Chanut, 'Comment Hollande et Valls veulent sortir du piège de la fin de l'état d'urgence,' La Tribune 4 December 2015: 31. ${ }^{50}$ Jacquin and Pascual, 'Un an,' SPA3.
} 
that we could stop a moment to deepen certain reflections [that began the previous year].' Songy 'stop[ped] a moment' in a transitive sense. In the words of his interviewer Manuel Piolat Soleymat, he 'suspend[ed] time. ${ }^{151}$

This interruption in time was not a direct response to France's state of emergency; Songy does not mention the state of emergency in any public explanations of the renumbering of the 2016 festival. But the state of emergency is a suspension of time that makes this other, theatrical suspension of time differently intelligible, as a moment of grief and of grievance, an interruption in time created by extraordinary loss. The power of the theatrical suspension of time--something as simple as the renumbering of a festival--lies in its ability to mark the state of emergency as a suspension of time. Aurillac 30bis was a street theatre festival for an impasse: as Lauren Berlant would have it, 'a holding station that doesn't hold securely but opens out into anxiety,' a cul-de-sac in which activity, though necessary, lacks a clear endpoint and the forward momentum of narrative. ${ }^{52}$ How else is a festival to keep time during the strange, not-yet-bracketed period of the exception?

Rather than resume the following year with the $31^{\text {st }}$ or $32^{\text {nd }}$ edition (or continue the suspension of time with a still more unwieldy $30^{\text {th }}$ bis bis), Songy declared the 2017 Aurillac festival the $69^{\text {th }}$ edition. This act of re-numbering was a response to France's ongoing state of emergency, as Songy explained: 'Faced with the violence that has entered into our daily lives for two years, I appeal to the bacchanal rather than ballistics. ${ }^{53}$ Thus the point was not merely to project festivalgoers into an

\footnotetext{
${ }^{51}$ Manuel Piolat Soleymat, 'Festival international de théâtre de rue d'Aurillac: édition 30 bis,' interview with Jean-Marie Songy, La Terrasse no. 244 (24 May 2016).

Available at: https://www.journal-laterrasse.fr/festival-international-de-theatre-derue-daurillac-edition-30-bis/.

${ }^{52}$ Lauren Berlant, Cruel Optimism (Durham, NC: Duke University Press, 2011), 199.

53 Anaïs Heluin, 'Festival international de théâtre de rue d'Aurillac: édition 69,' interview with Jean-Marie Songy, La Terrasse no. 255 (29 May 2017). Available at:
} 
imagined future thirty-eight (or thirty-nine?) years hence, a point at which the state of emergency would hopefully have come to an end. The point was also to play on the carnal connotations of the chosen number in an unrepentant celebration of mutual bodily gratification. In interviewer Anaïs Heluin's words, Songy offered 'an invitation to love in these troubled times. ${ }^{154}$

Songy extended this invitation with help from the programmed street theatre companies, several of which staged shows featuring nudity and sexual content or otherwise foregrounding the body. In BRAME ou, tu me vois crier, Papa? (BELLOW or, do you see me screaming, Dad?), Compagnie AlixM took its 'spectator-trackers' on an urban hunting expedition, during which they encountered (among other startling sights) nude performers with antlers attached to their waists 'locking horns' like battling stags, simulated sex between performers dressed as a mayor and an officer of the riot police, and a group of four naked men and one naked woman frolicking atop an inflatable designed to resemble a giant tube of Vaseline. In its disturbing yet erotically charged Recette des corps perdus (Recipe of lost bodies), Ilotopie literalised capitalism's consumption of the body: performers removed sections of their clothing to reveal muscles and organs made of antipasti, which they offered to the mouths of hungry spectators. Thé à la Rue's Dévêtu(e) (Disrobed) invited spectators to change into knee-length spa robes before exploring a series of installations on the theme of the body. Some spectators simply put the robes overtop their clothes; most took advantage of private changing booths to undress completely.

Despite the explicit political imagery of a show like $B R A M E$, it would be easy to critique the hyper-sexualised festival as somehow escapist, a retreat from the realm

https://www.journal-laterrasse.fr/festival-international-de-theatre-de-rue-daurillacedition-69/.

${ }^{54}$ Ibid. 
of 'proper' politics to a dated and, frankly, creepy hippie commune of free love. (It might also preclude the participation of some religious spectators, including French Muslims.) And it would be easy for me to suggest, given my critiques of transgression as a political model for street theatre, that Songy has fallen into just such a trap. But in what follows I analyse the opening event of the $69^{\text {th }}$ Aurillac festival to suggest that its foregrounding of the flesh parodies the interplay of security and precarity, exposure and concealment, at the heart of the state of exception, and that it models alternative possibilities for being vulnerable, together, in public space.

On Wednesday, 23 August 2017, thousands of people gathered before the golden orange façade of Aurillac town hall for the official opening of the festival. Staff and volunteers circulated amongst the crowd and distributed orange armbands that read 'sexurité' (sexurity), a playful subversion of the festival's continuingly heightened security presence that also prefigured the eroticism to come. Soon the spectators' seated bodies covered the plaza save for the delineated performance spaces: a square immediately in front of the town hall entrance, cordoned off by a low red chain, and ten raised platforms dispersed throughout the crowd, each roughly two feet high and just large enough for three or four standing performers. The identities of the performers were not immediately obvious. Before long, however, one member of street theatre company Ilotopie, then another, then another, stood up from the crowd and began to disrobe. Eventually some thirty performers stood amidst the seated crowd, nude except for G-strings. Two to four performers moved to each of the ten raised platforms, where they then applied thick, glossy body paint to themselves and each other. Each pair or group coated themselves in a different, vivid colour: shocking pink, red, orange, yellow, lime and fern greens, turquoise, azure, cerulean, and lavender. Performers began by applying their own gloppy paint, but to cover the 
entire body, including backs, faces, and hair, soon required cooperation and acts of intimacy.

Street theatre aficionados would have recognised these proceedings as the latest iteration of Ilotopie's Gens de couleur (People of colour). In that long-running and widely touring production, similarly painted performers wander through the urban environment, attracting stares and interacting silently with passers-by. They seek out signs, vehicles, plants, architectural features, and other objects that match their colour and playfully pose against or alongside them. They move through markets, sampling produce or sweets in their chosen hue. At an appointed time, the performers reconvene in a public square and transform themselves into sculptures using liquid foam (again, in a matching colour) that hardens around their bodies. The central element of the performance, though, is the reaction of pedestrians to these strange beings. Video footage of a May 2017 performance in the picturesque centre of Calais, less than an hour's walk from the cleared site of the Calais Jungle refugee camp, shows predominantly white passers-by gawking, taking photographs, and honking car horns. Children point, exclaim, 'Look!' and ask their parents what is happening. The parents confess their ignorance. Other adults endeavour not to stare, studiously ignoring the nearly nude performers who sidle up to them to see if their bright clothes match their body paint. ${ }^{55}$ More so even than the flagrant pointing, these strained interactions shift the focus from the performers themselves to the fraught interpersonal and power dynamics of public space. Who feels comfortably a part of that public, and who is made to stand apart from it? Whose visibility is deemed unsightly? How does a public respond to foreign bodies, and what constitutes a body

\footnotetext{
55 Ilotopie has posted video footage of the May 2017 Calais performance online, available at: https://www.youtube.com/watch? $\mathrm{v}=\mathrm{fV}$ t53sMXbwo and https://www.youtube.com/watch?v=HmJRnUOZY5g.
} 
as foreign? Ilotopie's 'people of colour' stand out as so alien yet repeatedly find ways to blend in with or complement their surroundings. If these beings are radically 'other,' they also demonstrate their belonging.

While the performers of Ilotopie applied their body paint, another man--he, too, clad only in a G-string--scaled the façade of Aurillac town hall. His goal was clear: to raise atop the building the rainbow flag he carried with him, still furled, on his back. Though the climber used a visible security harness and two belayers, his ascent caused palpable tension amongst the crowd. His exposed flesh was vulnerable to the rough surface of the building. At times the climber would give his belayers his full weight, pushing slightly off the façade of the building to slowly flip or crawl in circles, or to comically pretend he was clinging to the top of a column by the tips of his fingers. When he finally reached the summit and stood atop the pediment, waving the rainbow flag, the spectators below erupted in cheers and applause.

What was a Pride flag doing at the Aurillac street theatre festival? Was it a Pride flag, or was the climber appropriating the rainbow flag to issue a more generic call for diversity? (One could be forgiven for assuming as much, since the climber held the flag upside down, with the purple stripe on top.) Press coverage of the event referred to the flag as a symbol for respect of sexualities or even for free love. I interpret it, however, as a stronger response to the state of emergency and the restriction of public space. During the state of emergency, the primary targets of newly empowered police were not LGBTQ+ people but Muslim people of colour (with the obvious caveat that some Muslim people of colour are also LGBTQ+). But, following Judith Butler, 'we might consider the right to appear as a coalitional framework, one that links gender and sexual minorities with precarious populations 
more generally. ${ }^{56}$ Gender and sexual minorities share with French Muslims the struggle to appear in public as they will, free from shame, harassment, and violence. The rainbow flag, evoking as it does the spectrum of visible light, offers a clear symbol of the fight for visibility. My point is not that the climber (or, for that matter, the rainbow performers of Ilotopie) intended to forge an alliance between French queers and French Muslims, nor even that their actions achieved such an effect. Rather, my point--which I continue to develop in my analysis of the rest of the inauguration, below--is that the politics of these performances, i.e. their modes of being political, gesture toward the possibility and indeed necessity of such an alliance, even if, in Aurillac in 2017, that potential remained unfulfilled.

Following the climber's successful ascent, Marie-Do Fréval of street theatre company Bouche à Bouche performed a portion of Tentative(s) de Résistance(s) (Attempt(s) at Resistance(s)), her contribution to the festival's official programme. Over the course of the weekend, Fréval would arrive at different locations around Aurillac, each time as a different character, and deliver rushed monologues, always interrupted, that spoke to the necessity of resistance whilst comically alluding to a sense of powerlessness. Her harried demeanour evoked the permanence of imminent threat in a state of emergency and the protest fatigue experienced by activists who must rush from outrage to outrage. Here she appeared as Marie de la Gaule [sic], a 'feminine incarnation' of Charles de Gaulle in a painted moustache and a poorly fitted mock-up of the general's iconic military garb. ${ }^{57}$ Fréval's queered, quick drag de Gaulle visually evoked French resistance to Nazi occupation and Vichy collaboration,

\footnotetext{
${ }^{56}$ Butler, Notes, 27-8.

${ }^{57}$ Compagnie Bouche à Bouche, Tentative(s) de Résistance(s), press dossier, 3. Available at:

https://www.cieboucheabouche.com/images/creations/Tentatives_Resistances/Tentati veS_de_ResistanceS.pdf.
} 
France's colonial legacy, and the Algerian War-era state of emergency that had laid the legal groundwork for France's contemporary war on terror. Fréval declaimed that she believed in 'resistant France' (la France résistante), but she also undermined the Gallic brand of manly mid-century militarism for which the general has become a symbol: 'Believe me, I tell you, nothing is lost, defeat is not definitive. For a people, the safest guiding star in the storm is fidelity to one's children and one's cheeses. Let each of us proudly raise his cabécou, his cantal, his comté, his camembert, his salers, his brie and his tome for the future of our lost youth, our humiliated women, our unhappy grandchildren, our mummies and daddies.' If French cultural identity proves hollow, it can at least be filled with cheese.

During Fréval's speech, a group of plainclothes performers assembled a large wooden lattice in the cordoned-off area of the plaza behind her. They placed two planks of wood, each some six metres long, parallel to each other on the ground, spaced just a few feet apart. They then placed two more planks on top of and perpendicular to these, and proceeded to build the lattice up and out from there. With each new layer, the planks were spaced further apart. The result was a precarious weave of eighteen planks in total, balanced upon a narrow base. Viewed from the side, some of the planks appeared to hover like floating steps.

After Fréval's speech and the assembly of the lattice, half of the colourful Ilotopie performers made their way through the crowd to the main performance space. Another performer in red livery spoke into a microphone, inviting brave spectators to test out 'the benefits of insecurity' (les bienfaits de l'insécurité). Ten audience members then joined the Ilotopie performers in stepping onto the wooden planks and moving about the lattice, eyes closed. The man in red livery continued to speak into the microphone, reassuring the balancing participants that, if they felt insecure, they 
could open their eyes and regain their footing before continuing. He also offered an arm to walkers who ventured to the far edges of the lattice. Once the participants seemed to have their balance, the liveried assistant became less vocal, and a small group of musicians began to play an acoustic cover of France Gall's 1981 single, 'Résiste.' Michel Berger's lyrics exhorted listeners to 'Resist / Prove that you exist,' but the vocal tone and melody of the classic chanson française were more sensual than militaristic. Those Ilotopie performers still on their scattered platforms moved languidly to the music, inviting nearby spectators to join them and offering them body paint to smear on themselves.

The performers and participants treading the boards moved cautiously as they blindly explored the wooden structure. Some shuffled in short steps, whilst others sought the next plank with slowly, tentatively extended feet. Because the lattice rested on a narrower base, rapid movement or uneven distribution of weight threatened to wobble or tilt the assembly. The blind walkers had to become hypersensitive to the position of their bodies in relation to the planks and to each other. They would sometimes gently bump into each other or deliberately seek out others through touch to get a clearer sense of their location or to regain their balance. These physical connections became more frequent as more performers and participants stepped onto the structure. As a result, the performers' body paint transferred to others, until no performer remained monochromatic and the audience volunteers were streaked in rainbow hues. On some bodies, full handprints showed the traces of close encounters: accidental collisions, reassurances, or rescues. No two bodies appeared the same--this was not a shift from difference to universalizing homogeneity--but each body became a visible record of its being-in-public with others. 
The inaugural performance concluded with a final balancing act, as a barebreasted woman arrived at the back of the crowd, standing atop a horse. The barebreasted woman, long a French symbol for liberty, persisted here as a symbol of strength (the core strength required to stand on top of a moving horse being not inconsiderable), but also as a symbol of precariousness, as the woman's tremendous effort to keep her balance was up-close and visible to the crowd. Seated spectators had to quickly grab their belongings and move out of the horse's path as it carried its rider to the front staging area, guided on a rope by an Ilotopie performer in green body paint. Those Ilotopie performers still amongst the audience abandoned their smaller platforms to follow horse, rider and guide as they made their way forward. Once all had reached the doors of town hall, the inauguration ended, and the festival began. Music played as the colourful bodies of Ilotopie moved freely around the crowded plaza, once more offering body paint to milling festivalgoers. Some attendees smeared colours onto their clothes or visible skin; others joined the performers in stripping off under the hot Aurillac sun.

The inauguration of Aurillac 2017 inverted the logics and practices of the state of exception. The security state that has emerged from the War on Terror places restrictions on public space in the interest of minimizing exposure to threat, all while exposing us (some more than others) to heightened and extrajudicial surveillance. The security state claims as its aim the impossible elimination of vulnerability. But that same security state perpetuates insecurity and differentially enforces precarity. During France's state of emergency, administrative searches violated the sanctity of the domicile, troubling the distinction between private and public. Through their nudity, the Aurillac performers (and the more confident spectators) critically mimicked the making public of private life. But these acts of exposure were also acts 
of concealment, as the performers of Ilotopie obscured their skin tones and hair colours in layers of thick paint. These bodies appeared exposed and vulnerable in public, but not in ways conducive to surveillance.

To be exposed is always to be vulnerable, but, in Butler's words, 'the body is exposed, to history, to precarity, and to force, but also to what is unbidden and felicitous, like passion and love, or sudden friendship or sudden and unexpected loss. ${ }^{158}$ This is why the inauguration's sensuality and eroticism marked an engagement with, rather than a retreat from, the politics of the state of emergency. From the distribution of parodic 'sexurité' armbands to the waving of the Pride flag, from the display of nude bodies to the invitation to discover 'the benefits of insecurity,' the event issued a reminder that to be in public is to be vulnerable, but that to be vulnerable is to open oneself to being with others in ways that are necessary for the flourishing of human life. The inauguration's multiple balancing acts foregrounded, not the strength or resilience of individual, autonomous bodies, but the support structures that made possible the appearance and actions of those bodies: the harness, ropes, and belayers protecting the climber; the wooden planks, liveried speaker, and fellow participants assisting the blind walkers; and the reins, horse, and guide supporting the bare-breasted woman. To borrow again from Butler, who has observed a similar phenomenon in contemporary anti-precarity social movements, these performances did not attempt to overcome vulnerability; rather, they modelled our inherent and necessary interdependency. Vulnerability and interdependency are not always comfortable, but, given the proper conditions of support, they become liveable. ${ }^{59}$ This is not to say that we should turn our attention to precariousness 'as a

\footnotetext{
${ }^{58}$ Butler, Notes, 148.

${ }^{59}$ Ibid. 69, 218.
} 
relational condition of social being that cannot be avoided' at the expense of critiques of differentially distributed material and corporeal insecurity. ${ }^{60}$ Rather, it is to contend that an insistence on the fundamental relationality of all life must be part of such critique, as a repudiation of the tortured logics of the state of exception.

\section{Conclusion: Street Theatre's Bind, Street Theatre's Impasse}

Writing shortly after the declaration of the state of emergency in November 2015, legal historian François Saint-Bonnet expressed his concern that parliamentary approval was given in a state of heightened emotion. He called for patience and a return to 'a logic of reasoned and reasonable vigilance.' ${ }^{61}$ The desire for caution is understandable. Ultimately, though, I reject the neat distinction between emotional proximity and rational distance, which elsewhere has been used as a rhetorical device to foreclose on (for instance) the introduction of gun control legislation in the immediate aftermath of mass shootings. Like the characters of Marie-Do Fréval, subjects of the security state do not have time to catch their breath before the next horror is perpetrated. Fear and uncertainty will not subside, in part because they are perpetuated by the very mechanisms that claim to combat them. In her own reflections on the days after the Bataclan attacks, Judith Butler, too, cautioned against letting fear and rage dictate action: 'I prefer those who find themselves at an impasse. That means that this will take some time to think through. It is difficult to think when

\footnotetext{
${ }^{60}$ Isabell Lorey in Jasbir Puar, ed., 'Precarity Talk: A Virtual Roundtable with Lauren Berlant, Judith Butler, Bojana Cvejic, Isabell Lorey, Jasbir Puar, and Ana Vujanovic,' TDR: The Drama Review 56.4 (2012): 163-77 (165). Contributors to this roundtable also rightly note that precarity is not new. Berlant, in particular, observes that what is ordinary for the working class is read as crisis when it begins to affect the bourgeoisie. We could adapt this assertion to the more specific case of France's state of emergency: what is normal for French Muslims in the banlieues becomes a crisis when it affects a street theatre festival.

${ }^{61}$ Saint-Bonnet, 'Plus la latitude,' n.p.
} 
one is appalled. It requires time, and those who are willing to take it with you. ${ }^{62}$ What is needed, then, is what Songy might call rattrapage, not a way to move beyond feeling but a way of thinking and feeling differently, a different mode of being vulnerable, together, with others. To foster such a mode, to stage experiments in the constitution of interdependent publics and the spaces that might support them, is the task of street theatre in a state of exception.

Street theatre, an apparent suspension or overturning of everyday rule, relies for its very existence on a rule of law that, in the state of exception, has been suspended, and on a public space indissociable from the very public order it would seek to disrupt. This is street theatre's bind. But, though street performers make claims to public space at some risk, they do not do so in error. That bind is valuable insofar as it lays bare the logics of the exception at the heart of liberal polity and indicates the necessity of contesting the conceptualization and construction of public space. This project need not be confined to France. Just as the conditions that necessitate it--the securitisation and privatisation of public space, the grounding of such space in the maintenance of public order, the indefinite extension of imminent threat, the limitations of rights discourse, the exclusions undergirding supposedly universalist humanism--extend beyond French borders to other liberal democracies, so too can the performances that navigate those conditions.

Paradoxically, the disorder of street theatre keeps open a bridge between order and law, flitting between the two. Street theatre is neither paralysed nor hopelessly outmanoeuvred. On the contrary, through its use of exposure and disguise, arrangements of performers' and spectators' bodies, and theatrical re-scripting of

62 Judith Butler, 'Mourning becomes the law,' Verso Books blog, 16 November 2015 (http://www.versobooks.com/blogs/2337-mourning-becomes-the-law-judith-butlerfrom-paris). 
spaces and times, street theatre is able to question which forms of security are desirable and which forms of precariousness are liveable. This is street theatre's impasse: not a time or space from which we might move on, but from which we might take exception to the exception. Playing on such an impasse, street theatre can critically mimic the logics of the exception so as to model how publics and their spaces might take form through the shared vulnerability of selves and others. 